\title{
Intranuclear inclusions in neural cells with premutation alleles in fragile $X$ associated tremor/ataxia syndrome
}

\author{
F Tassone, R J Hagerman, D Garcia-Arocena, E W Khandjian, C M Greco, P J Hagerman
}

J Med Genet 2004;41:e43 (http://www.jmedgenet.com/cgi/content/full/41/4/e43). doi: 10.1136/jmg.2003.012518

F ragile $\mathrm{X}$ syndrome is generally considered to be a non-progressive neurodevelopmental disorder in which carriers of premutation alleles ( $\sim 55$ to 200 CGG repeats) of the fragile $\mathrm{X}$ mental retardation $\mathrm{l}$ (FMRl) gene are largely unaffected. However, we have recently identified a new syndrome among male carriers, characterised by tremor and/or ataxia, cognitive deficits, parkinsonism, and autonomic dysfunction. ${ }^{156810}$ Neuroradiological findings include moderate to severe cortical atrophy (cerebral and cerebellar cortical volume loss) and characteristic hyperintensities on T2-weighted MR imaging of the deep cerebellar white matter and middle cerebellar peduncles. ${ }^{2}{ }^{8}$ The disorder, termed fragile $X$ associated tremor/ataxia syndrome, ${ }^{8}$ has been observed thus far almost exclusively in older adult male premutation carriers of more than 50 years of age.

Eosinophilic intranuclear inclusions are broadly distributed in both neurones and astrocytes throughout the cerebrum and brain stem of all persons with fragile $X$ associated tremor/ataxia syndrome (FXTAS) examined to date $(8 / 8),{ }^{57}$ with the greatest numbers of neuronal inclusions found in the hippocampus. No inclusions were detected in the Purkinje cells, although axonal degeneration and Purkinje cell loss were prominent findings in the cerebellum. ${ }^{5}$

Premutation carriers generally have elevated FMRI mRNA levels, suggesting that FXTAS could result from a toxic gain of function of the FMRl mRNA. ${ }^{568}$ To determine whether inclusion formation and clinical involvement are associated with allelic mosaicism, we defined the size of the CGG expansion and the relative expression levels of the FMRl gene in various regions of the brain of a male premutation carrier who died with neurological symptoms consistent with FXTAS, and whose neural cells possessed numerous intranuclear inclusions. Analysis of multiple brain regions was undertaken to demonstrate that premutation alleles were directly associated with inclusion formation, and that full mutation alleles, even if present at low levels, could not account for inclusion formation.

\section{MATERIALS AND METHODS \\ Clinical history}

The individual studied was a carrier of an FMRl premutation allele of 113 CGG repeats, and died of pneumonia at 70 years of age. Clinical involvements of this case have been already reported (case 1$).^{5}$

\section{Tissue preparation}

The samples from specific brain regions of this carrier that were used for the histological analysis were taken from the left cerebral hemisphere fixed in formalin. The postmortem intervals for the brains derived from the premutation carrier (aged 70 years) and from normal male control (aged 69 years) were 10 and 12 hours, respectively.

\section{Key points}

- The presence of a large premutation allele, of the same size in all brain tissue regions analysed as well as in peripheral blood leucocytes, demonstrated both somatic stability in this size range and the association between FMRI premutation and fragile $\mathrm{X}$ associated tremor/ataxia syndrome (FXTAS).

- In the premutation carrier FMR1, mRNA levels were elevated in both peripheral blood leucocytes and in several brain regions, relative to normal controls.

- Frequent intranuclear inclusions were present in ependymal and subependymal cells, and in the epithelial lining cells of the choroids plexus from a premutation carrier brain.

- Intranuclear inclusions and clinical involvement in FXTAS were associated with the presence of an FMR1 premutation allele.

\section{Neuropathology studies}

Standard techniques, including haematoxylin and eosin staining and immunohistochemistry, were used for the neurohistological analysis. Details of the methodology were as described by Greco et al (2002).

\section{DNA analysis}

Genomic DNA was isolated from peripheral blood leucocytes ( $5 \mathrm{ml}$ of whole blood) before death, and from postmortem sections of about $500 \mathrm{mg}$ of brain tissue using standard methods (Puregene Kit, Gentra, Minneapolis, USA). For Southern blot analysis, 5-10 ug of isolated DNA was digested with EcoRI and NruI and transferred to a charged nylon membrane using a vacuum transfer apparatus. Membranes were hybridised with the FMRI genomic probe StB12.3 labelled with Dig-11-dUTP by PCR (PCR Dig Synthesis Kit, Roche Diagnostics, www.roche-diagnostics.us). Filters were exposed to $x$ ray film for two hours. For PCR analysis, DNA was amplified using primers $\mathrm{c}$ and $\mathrm{f}^{4}{ }^{4}$ PCR products, separated on $6 \%$ denaturing polyacrylamide gels, were transferred to a nylon membrane. Filters were hybridised with a Dig end labelled oligonucleotide probe (CGG) ${ }_{10}$, and were washed before detection of the FMRI PCR products. Filters were exposed to $x$ ray film for one hour.

\section{FMR 1 mRNA expression levels}

Total RNA was isolated from peripheral blood leucocytes (approximately $3 \mathrm{ml}$ ) before death and from postmortem brain tissue using standard methods (Purescript, Gentra, 
Minneapolis, USA). Reverse transcriptase reactions and QRTPCR were carried out as described by Tassone et al (2000). ${ }^{12}$

\section{FMRP expression levels}

FMRP expression from peripheral blood leucocytes was determined by immunocytochemistry as the percentage of FMRP positive lymphocytes. ${ }^{13}{ }^{14}$ FMRP expression levels in brain samples were determined by Western blot analysis according to standard methods. ${ }^{3}$ After immunoblot analysis, the films were scanned, and densitometric analysis was carried out by measuring and quantifying the band intensity using the NIH Image $1.62 \mathrm{f}$ program.

\section{RESULTS}

\section{Neuropathological studies}

As previously reported, extensive neurohistological studies revealed the presence of ubiquitin positive, intranuclear inclusions in both neuronal and astrocytic cells, with highest frequencies ( $\sim 38 \%$ of neuronal nuclei) in the hippocampus. ${ }^{5}$ A pronounced dropout of Purkinje cells, and occasional axonal torpedoes, were also observed. ${ }^{5}$ We have since found intranuclear inclusions in ependymal and subependymal cells (fig 1), and in the epithelial lining cells of the choroids plexus.

\section{Molecular studies}

Sizing of the CGG repeat within the FMRI gene, by both Southern blot and PCR analysis, demonstrated the presence of a premutation allele of 113 CGG repeats in peripheral blood leucocytes and in 13 different brain samples, thus demonstrating a lack of any interregion allelic size heterogeneity. Southern blot analysis revealed the presence of a single premutation allele and the absence of detectable full mutation alleles.

FMRI mRNA levels showed an almost fourfold increase (3.8, SD 0.13) in peripheral blood leucocytes relative to normal controls, consistent with previous findings in premutation carriers. ${ }^{912}$ The relative brain FMRl mRNA levels were substantially higher than in peripheral blood leucocytes, relative to the reference gene (glucoronidase, GUS), in the brains of both carrier and control (table 1). However, the net increase in the carrier cerebral levels relative to the control $(1.5, \mathrm{SD} 0.12 ; \mathrm{p}=0.02)$ was much less
Table 1 Quantitative RT-PCR measurements of relative FMR1 mRNA levels

\begin{tabular}{llll}
\hline \multicolumn{4}{c}{ Relative FMR1 mRNA levels } \\
\cline { 2 - 4 } Tissue & Carrier & Normal & Ratio \\
\hline Peripheral blood leucocytes & $3.8 \pm 0.13$ & 1.0 & 3.8 \\
Amygdala* & $10.4 \pm 0.58$ & $6.95 \pm 0.16$ & 1.5 \\
Frontal cortex* & $9.04 \pm 0.57$ & $6.8 \pm 0.74$ & 1.32 \\
Hippocampus* & $7.1 \pm 0.41$ & $5.2 \pm 0.48$ & 1.4 \\
Temporal cortex* & $15.3 \pm 0.85$ & $9.3 \pm 0.72$ & 1.6 \\
Occipital cortex* & $5.18 \pm 0.27$ & $3.62 \pm 0.26$ & 1.4 \\
Cerebellum & $6.1 \pm 0.36$ & $7.11 \pm 0.35$ & 0.9 \\
\hline *Mean of the five tissues $=1.45 \pm 0.12$. & & \\
\hline
\end{tabular}

pronounced than in blood leucocytes, and no difference was observed for cerebellar cortex. This last observation is intriguing in view of the fact that cerebellar cortex is the only brain region devoid of inclusions; the significance of this observation is not known at present.

Immunocytochemical analysis showed a moderate FMRP deficit in peripheral blood leucocytes, with $62 \%$ of FMRPpositive lymphocytes. Western blot analysis revealed a more pronounced FMRP deficit in three brain regions. Specifically, FMRP expression levels were found to be $0.34,0.45$, and 0.92 relative to normal in hippocampus, temporal cortex, and frontal cortex, respectively. The observed FMRP deficit was consistent with a defect in the translation efficiency of FMRl premutation alleles as recently reported..$^{11}$

\section{DISCUSSION}

The presence of intranuclear inclusions in all brains derived from individuals with FXTAS examined to date is strongly supportive of an association with the premutation alleles of the FMRl gene, since the clinical manifestations of the tremor/ataxia syndrome have not been observed in males with a full mutation. From Southern blot analysis, we can now reject the hypothesis that inclusions, and presumably disease formation, are a consequence of allelic mosaicism. However, before the current report, the presence of cryptic full mutation alleles that might be responsible for inclusion formation could not be ruled out. The presence of a large
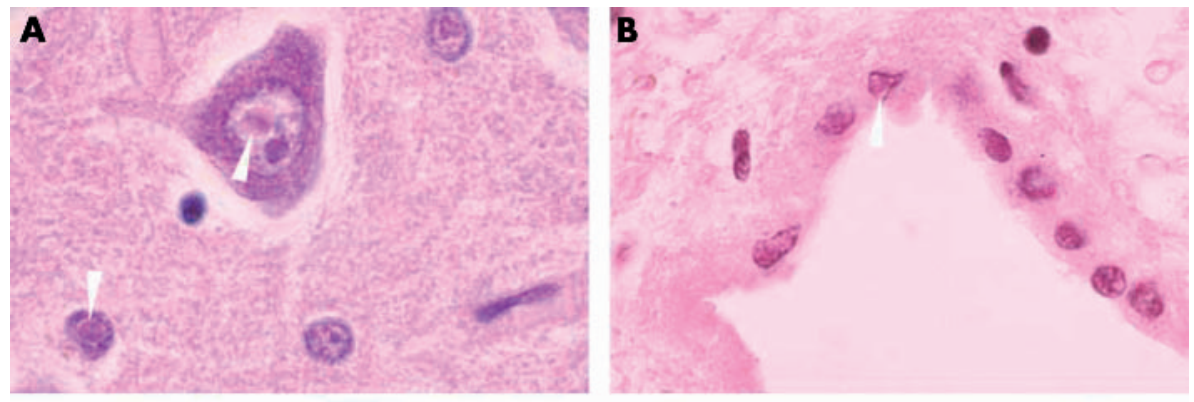

Figure 1 Intranuclear inclusions are visible in neurons and astroglia $(A)$ as well as in ependymal cells $(B)$, stained with haematoxylin and eosin $(\times 1000$ magnification). Staining of intranuclear inclusions with anti-ubiquitin antibodies are seen in astroglia neurones (C), and ependymal cells (D).
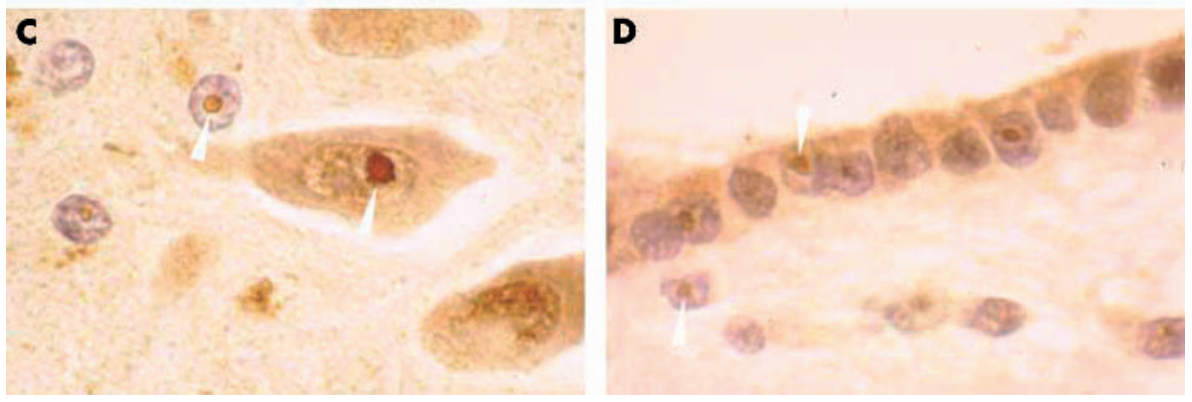
premutation allele of the same size in all brain tissue regions analysed, as well as in peripheral blood leucocytes, in one premutation carrier, demonstrates both somatic stability in this size range and the association between FMRl premutation and FXTAS.

Further support for the association of premutation alleles and inclusions comes from the recent observation that ubiquitin positive intranuclear inclusions have been observed in brains of mice with premutation (CGG) repeat expansions. ${ }^{15}$ Both the mice with expanded CGG repeat numbers, and all FXTAS patients so far analysed, have shown elevated levels of FMRl transcripts relative to normal, suggesting that elevated FMRl message might contribute to the neuropathology of FXTAS

Finally, we have observed intranuclear inclusions in ependymal cells, subependymal cells, and the epithelial lining cells of the choroids plexus. Subependymal cells include multipotential stem cells which can give rise to astrocytes, oligodendrocytes, and neurons, as well as fully differentiated astrocytes, which participate in reactive processes in the subventricular zone. Epithelial lining cells of the choroids plexus, which are responsible for cerebrospinal fluid production and secretion, are derived from ependymal cells early in fetal development. The presence of inclusions in these three cell populations is not yet understood, but may be related to a shared lineage with astrocytes, perhaps in a common basic cellular function.

\section{ACKNOWLEDGEMENTS}

This work was supported by the National Institutes of Child Health and Human Development (HD 40661; PJH), and by the U C Davis M.I.N.D. Institute.

\section{Authors' affiliations}

F Tassone, D Garcia-Arocena, P J Hagerman, Department of Biological Chemistry, School of Medicine, University of California Davis, CA, USA R J Hagerman, M.I.N.D. Institute and Department of Pediatrics, University of California Davis Medical Center, Sacramento, CA, USA E W Khandjian, Department of Medical Biology, Laval University, Quebec, Canada

C M Greco, Department of Pathology, University of California Davis Medical Center, Sacramento, CA, USA

Correspondence to: F Tassone, Department of Biological Chemistry, UC Davis School of Medicine, One Shields Avenue, Davis, CA 95616, USA ftassone@ucdavis.edu

\section{REFERENCES}

1 Berry-Kravis E, Lewin F, ScM JW, Leehey M, Hagerman RJ, Hagerman PJ, Goetz CG. Tremor and ataxia in fragile X premutation carriers: blinded videotape study. Ann Neurol 2003;53:616-23.

2 Brunberg J, Jacquemont S, Hagerman R, Berry-Kravis E, Grigsby J, Leehey M, Tassone F, Brown T, Greco C, Hagerman P. Characteristic MR imaging findings in adult males with progressive cerebellar and cognitive dysfunction. Am J Neuroradiol 2002;23:1757-66.

3 Corbin F, Bouillon M, Fortin A, Morin S, Rousseau F, Khandjian EW. 1. The fragile $X$ mental retardation protein is associated with poly $(A)+$ mRNA in actively translating polyribosomes. Hum Mol Genet 1997;9:1465-72.

4 Fu YH, Kuhl DP, Pizzuti A, Pieretti M, Sutcliffe JS, Richards S, Verkerk AJ, Holden JJ, Fenwick RG Jr, Warren ST, Oostra BA, Nelson DL, Caskey CT. Variation of the CGG repeat at the fragile $X$ site results in genetic instability: resolution of the Sherman paradox. Cell 1991;67(6):1047-58.

5 Greco CM, Hagerman RJ, Tassone F, Chudley AE, Del Bigio MR Jacquemont $S$, Leehey $M$, Hagerman PJ. Neuronal intranuclear inclusions in a new cerebellar tremor/ataxia syndrome among fragile $X$ carriers. Brain 2002; 125:1760-71.

6 Hagerman RJ, Leehey M, Heinrichs W, Tassone F, Wilson R, Hills J, Grigsby J, Gage B, Hagerman PJ. Intention tremor, parkinsonism, and generalized brain atrophy in male carriers of fragile X. Neurology 2001;57:127-30.

7 Hagerman PJ, Iwahashi C, Babineau B, Yasui D, Greco CM, Duncan M, Graw S, Kim F, Hagerman RJ. Fragile X associated tremor-ataxia syndrome (FXTAS): a common heritable neuronal inclusion disorder. Neurology 2003;60:A469.

8 Jacquemont S, Hagerman RJ, Leehey M, Grigsby J, Zhang L, Brunberg JA, Greco C, Des Portes V, Jardini T, Levine R, Berry-Kravis E, Brown TW Schaeffer S, Kissel J, Tassone F, Hagerman JP. Fragile X premutation tremor/ ataxia syndrome: molecular, clinical, and neuroimaging correlates. Am J Hum Genet 2003;72:869-78

9 Kenneson A, Zhang F, Hagedorn CH, Warren ST. Reduced FMRP and increased FMRI transcription is proportionally associated with CGG repeat number in intermediate-length and premutation carriers. Hum Mol Genet $2001 ; 10(14): 1449-54$.

10 Leehey MA, Hagerman RJ, Landau WM, Grigsby J, Tassone F, Hagerman PJ. Tremor/ataxia syndrome in fragile $\mathrm{X}$ carrier males. Mov Disord 2002;17(4):744-5.

11 Primerano B, Tassone F, Hagerman RJ, Hagerman JP, Amaldi F, Bagni C. Reduced FMR 1 mRNA translation efficiency in fragile $X$ patients with premutations. RNA 2002;8(12):1482-8.

12 Tassone F, Hagerman RJ, Taylor AK, Gane LW, Godfrey TE, Hagerman PJ. Elevated levels of FMRI mRNA in carrier males: a new mechanism of involvement in fragile X syndrome. Am J Hum Genet 2000;66:6-15.

13 Willemsen R, Mohkamsing S, de Vries B, Devys D, van den Ouweland A, Mandel JL, Galjaard H, Oostra B. Rapid antibody test for fragile X syndrome. Lancet 1995;345: 1147-8.

14 Willemsen R, Smits A, Mohkamsing S, van Beerendonk $H$, de Haan A, de Vries B, van den Ouweland A, Sistermans E, Galjaard H, Oostra BA. Rapid antibody test for diagnosing fragile $X$ syndrome: a validation of the technique. Hum Genet 1997;99:308-11.

15 Willemsen R, Hoogeveen-Westerveld M, Reis S, Holstege J, Severiinen L-A, Nieuwenhuizen IM, Schrier M, van Unen L, Tassone F, Hoogeveen AT, Hagerman PJ, E Mientjes EJ, Oostra BA. The FMRI CGG repeat mouse displays ubiquitin-positive intranuclear neuronal inclusions; implications for the cerebellar tremor/ataxia syndrome. Hum Mol Genet 2003; 12(9):949-959. 